\title{
Getting in, getting out and getting back: Conducting long-term research in immigration detention centres.
}

\author{
Mary Bosworth, (University of Oxford and Monash University) and Blerina \\ Kellezi (Nottingham Trent University) \\ Forthcoming in S. Armstrong, J. Blaustein and A. Henry (Eds). Reflexivity and \\ Criminal Justice: Intersections of Policy, Practice and Research. London: \\ Palgrave Macmillan.
}

\section{Introduction}

In this chapter we document challenges we face in conducting ongoing research on everyday life in immigration removal centres (IRCs) many of which relate to the highly contested nature of these sites. Immigration detention is frequently in the news, yet rarely the topic of independent academic scrutiny. The Home Office and the private companies who manage these sites of confinement hardly ever allow researchers into them, leaving most of those who write about such places dependent on NGOs, former detainees or evidence gleaned from conversations in the visits halls. We are the exception to the rule, having obtained and retained permission to enter IRCs to conduct independent academic research in 2009. In this chapter, drawing on interviews and field notes with and about staff, we explore some of the tensions inherent in maintaining a working relationship over a long period of time and in these complex research sites. Though aspects of our experience are specific to IRCs, some will apply to other, long-term research projects in custody.

The research on which this chapter is based, took over a year to arrange. In Autumn 2009, after numerous discussions, proposals, and appointments with men from the custodial sector in Britain, Mary finally met the civil servant who had the power to decide whether or not she could conduct her long-planned study of everyday life in immigration detention centres. Nobody had ever been given permission from the Home Office, she was warned; she was certain to be turned down. Understandably nervous, Mary was taken aback to realize that, unlike the senior custodial staff who had been assisting her up to that point, the man in charge of the decision was her own age. Expecting to negotiate with an older, more suspicious, man, she immediately felt more optimistic. Indeed, the young, and friendly, civil servant had already made his decision. She was welcome to start whenever she liked and he looked forward to hearing more about her findings. His one caveat, to which we shall return below, "we don't want your research to embarrass us." (Home Office, senior civil servant).

Since that date, Mary has been conducting research inside immigration detention centres, free from scrutiny, and, despite producing a series of critical reports, articles, blog posts, conference papers, and a research monograph, without interference (see, for example, Bosworth, 2012; 2013; 2014). The first study has led to a number of other projects, deploying a range of methodologies from 
surveys to photography. The original civil servant has long since moved on (to the private sector). Not all of his replacements have been as enthusiastic about facilitating academic research yet none of them have terminated it either. They maintain a wary acceptance.

In July 2010 Mary was joined by Blerina, who for 18 months, worked alongside her in three IRCs: Yarl's Wood, Tinsley House and Brook House. Mary is currently heading a 5-year research project on immigration detention, and has a number of students who are conducting research in and on these centres. Blerina continues to collaborate on some of these projects (Bosworth and Kellezi, 2012; 2013; 2014; 2015).

This chapter describes our work together, focusing on the first portion of our research into 'quality of life' in IRCs, in order to explore the ramifications and nature of conducting work in secretive, politicised sites like these. While we are grateful for the research access we enjoy, we reflect on the possible costs of the permission we have been given, as well as the challenges we have encountered in maintaining it. Whereas researchers are accustomed to negotiating consent with participants, they spend rather less time discussing the role of institutional gatekeepers in facilitating their projects. As a result, research access, if it is discussed at all, is often cast as a one off arrangement, granted or withheld.

When projects stretch over some years, as ours has, matters are not so straightforward. Relationships with gatekeepers evolve and shift. The top-level decision-makers themselves rarely stay in post, yet the institutions remain. The researchers publish findings, which, in sites like these, are rarely positive. They may also develop new areas of interest, and wish to move on from their original focus. Impression management attempts that may be made in one or two meetings, to disguise or deflect questions about personal opinions and intent are unsustainable over the long term. Researchers have to, at least in part, show their true colours.

While the Home Office has continued to support projects associated with the first one they authorised, they have not extended the same openness to other academics. Under these circumstances, thinking reflexively about access is urgently needed. In so doing, we hope not only to assist others seeking entry to the field but also to contribute to academic understanding of immigration detention itself. As we will argue below, methodology and the research process illuminate and are structured by quite fundamental aspects of daily life in detention that, in turn, connect to, and may shed light on, wider questions about their purpose and effect.

\section{The research context}

Immigration detention centres are relatively new sites of criminological inquiry (Bosworth, 2014; Aas and Bosworth, 2013). In the UK, there are around 4000 people held on any one day in one of 11 immigration removal centres (IRCs). Over the course of a year nearly 40,000 people pass through these sites of confinement. 
IRCs are concentrated in the South East of the country, with four situated adjacent to Gatwick and Heathrow airports. Though a national system, each institution is contracted out to a private custodial company or to the prison service. These custodial organisations run the IRCs on behalf of the Home Office according to the Detention Centre Rules, 2001.

Although not part of the criminal justice system, detention centres share many characteristics with more familiar penal institutions. They are, for the most part, built to Category B prison design, or are former prisons that have been converted into IRCs. They are staffed by uniformed 'detention custody officers' (DCOs) and 'detention custody managers' (DCMs), who are overseen by a small nonuniformed 'senior management team' (SMT). All centre managers are former prison governors and many in the Home Office have previously worked in the National Offender Management Service (NOMS) or in the Ministry of Justice. In addition to the custodial officers, each IRC houses a complement of onsite Immigration Officers, whose job is to communicate with the off-site Home Office case-workers who make all the immigration decisions concerning the detainees.

IRCs are inspected by the same groups that monitor prisons: HM Inspectorate of Prisons (HMIP), the Independent Monitoring Board (IMB) and the Prison and Probation Ombudsman (Bosworth, 2007). A number of detainees have served prison sentences, sometimes for immigration related offences, but often for more 'everyday' criminal matters like armed robbery or drugs. A handful of them are on multi-agency public protection arrangements (MAPPAs), having been convicted prior to detention of serious violent or sexual offences. Finally, daily life in these closed institutions is shaped by a series of instruments and tools from Detention Custody Orders to room share and risk assessment policies all of which originated in prisons and have merely been adjusted for their new population and setting.

These similarities assisted Mary in her initial bid to enter IRCs as she was able to draw on existing research relationships in the prison service to find a pathway into the Home Office. A retired prison governor introduced Mary to a centre manager and the head of a custodial company, both of whom, after one meeting, recommended her project to the Home Office. Like her original contact, the centre manager and the CEO, had previously been prison governors too. All had reservations about how IRCs were operating. They believed in the 'Decency Agenda' of the prison service and hoped it could somehow be transposed to detention centres. All were aware of and supported the prisons research centre at the University of Cambridge, which has worked for many years alongside prison staff to understand and ameliorate prison life. Perhaps Mary, at Oxford, could achieve a similar goal in detention, they proposed.

Like our early gatekeepers, when we began our project, we expected to draw on tools and ideas from prison sociology (Bosworth, 1999; Liebling, 2004; Crewe, 2009; Philips, 2010). Not only did we expect to find an environment in which 
regime and relationships were important, but we thought we could rely on similar methodologies and concepts to explain them. One of the strategies that had proved useful in gaining access, proposing to design and implement a new survey, the Measure of the Quality of Life in Detention (MQLD) (Bosworth and Kellezi, 2013; 2015), was explicitly modeled on Alison Liebling's Measure of the Quality of Prison Life (MQPL) (Liebling, 2004) which has been adopted by the prison service. Both instruments draw on extensive qualitative research with staff and the incarcerated. Both seek to quantify aspects of daily life to assist with progressive policy development.

As we will detail below, however, matters did not always work out as we had anticipated. While some ideas and techniques could be easily adjusted, others did not translate at all. The surveys have ended up being quite distinct while the process of gathering a meaningful sample in these uncertain sites remains extremely challenging.

Such methodological issues intersected with and were often amplified by the absence of an existing body of literature on these places as research sites. The lack of experience among staff and detainees as research subjects sat uneasily alongside the politicization of the sites in which they were found. We were often the very first academics anyone had actually met. Explaining our ideas and the purpose of study, under these conditions, was difficult, and raised uncomfortable questions about our capacity to gather informed consent. What were people agreeing to? And why would they participate? Paradoxically, the lack of a research culture and was also, at times, liberating. Few staff or detainees had preconceived ideas or expectations about us. As a result, once we had obtained research access, we had considerable flexibility in what we could do, where we could go, and the kinds of questions we could ask.

\section{Getting in}

Research access is made up of a series of interactions, of which 'getting in,' in a formal sense, is only the first. Once inside, researchers must attract participants. They also need to understand the site they have entered. In custodial research, these tasks, of engagement and comprehension, can be particularly challenging due to the well-known and extensively documented power differences among the confined and those who secure them (see, inter alia, Sparks, Bottoms and Hay, 1996; Bosworth, 1999; Crewe, 2009; Phillips, 2010). Each side may be wary of cooperating with a researcher. In detention, matters are made still more complicated by the sheer array of staff and detainees and by the distinct and still largely unfamiliar nature of these establishments.

In contrast to the long tradition of prison sociology, very little academic work has been conducted inside detention centres (Hall, 2010; 2012; Bosworth, 2012; 2014; Bosworth and Kellezi, 2014). Instead, for the most part, academic scholarship on detention is either purely theoretical (De Genova, 2010; Silverman and Massa, 2012), is based on interviews with former detainees (Klein and Williams, 2012) or relies on information gleaned from social visits (Griffiths, 2014). Before we began there was little other than reports from NGOs and the 
government to prepare us for what detention was like (HMIP, 2002; Phelps, 2009). Until 2010, when Alexandra Hall published an article on her doctoral research with staff in a British detention centre she refers to as 'Locksdon', there was nothing at all about detention as a research site (Hall, 2010; see also Hall, 2012).

While all of this scholarship contributes to our understanding of the impact, nature and justification of border control, the growing distance between the interior life world of these sites of confinement and the academic and political debate over them raises some uncomfortable questions. While it is clearly not the case that only empirical accounts can explain carceral institutions, without any systematic, independent scrutiny, our understanding of them is inevitably limited. At the same time, there are also risks and costs associated with institutional studies. Asking people to reflect on traumatic experiences while they are still undergoing them can be painful. Some might argue that entering these sites could, however unintentionally, legitimate them. How bad can they be, people may ask, if researchers are able to visit?

Such queries demand a response. Institutional ethnographies cannot uncover the 'truth' but they can illuminate hidden spaces and the experiences of those within by gathering testimonies, describing day-to-day activities, and bearing witness to life inside. Without such detail, theoretical and political debate becomes unhinged from the very lives it seeks to understand or improve. 'Bearing witness', as Emma Kaufman (2015) observes, is a form of recognition. In sites like IRCs, which are designed to expel, face-to-face encounters are inherently political. It is no wonder, then, that the state is so unwilling to allow outsiders entry.

On a more personal level, the absence of scholarship placed us, in the beginning at least, in an uncertain position. The politicization of these sites can be disorienting, as it is difficult to separate research from normative questions about the morality of locking up people on the basis of their immigration status. Confusion about these sites and concerns about their legitimacy weighed heavily on us at all stages of the project, and continue today. In these uncomfortable feelings, we glimpse what it might be like to enter or work in IRCs as those within are also often unclear and anxious about them.

Even today, six years into the research field, entering detention centres is unsettling. Although there is some variation in their architectural design and levels of security, they are all ringed with razor wire and CCTV cameras. Researchers, as well as staff and visitors, may be searched on entry. They are only allowed to bring in with them certain pre-authorised items.

\section{FIGURE 2: EXTERNAL IMAGE CAMPSFIELD HOUSE}

Natural light in most IRCs is restricted. Hallways stretch, lined with locked, or at least closed, doors. Sections of the building end suddenly with barred doors. The institutional smell of cleaning fluids pervades. In certain sections, often the legal 
corridor where meetings about deportation occur, the odour of nervous sweat can be overwhelming.

\section{FIGURE 3: CORRIDORS COLNBROOK}

As in prisons, sound is both muffled and occasionally piercing. Detention centres ring with the jangling of keys, slamming doors and, sometimes, raised voices. Some of the institutions we visited used a tannoy system to call individuals to meet immigration officers, lawyers or visitors, although most have subsequently ended this practice. In the more highly secure facilities, corridors linking the housing units and activities areas can be over-run with men or women as they move during specific periods of the day, but otherwise sit silent, with all the activity occurring behind heavy metal doors that block the noise.

\section{FIGURE 4: HOUSING BLOCK MORTON HALL}

Unlike prisons, mobile phone ringtones punctuate the day. So, too, the chatter of voices and snatches of melody are rarely in English. In Brook House, when we conducted our research, the area outside the centre shop ${ }^{1}$ was particularly raucous as men sat playing dominoes, crashing their pieces together loudly and shouting. Those institutions situated alongside or adjacent to Gatwick and Heathrow airports vibrate with noise from the runway, as plane after plane takes off or lands, reminding those within of the state's intention for them.

In sites of research, these issues matter. Not only are some of them difficult to navigate, but they also reveal important qualities of daily life. Most obviously, our ability to communicate with those confined was attenuated in an environment designed to hold foreigners. While most people in detention speak some English, few are fully fluent. On occasion we brought in interpreters or drew on our own foreign language skills. Yet, due to the logistics of research access which made it difficult to bring in interpreters, we conducted most of our interviews and administered nearly all the surveys in English, using our own foreign languages where possible.

Elsewhere we have written at some length about the impact of such matters on understanding as well as their effect on immigration detainees (Bosworth and Kellezi, 2012; 2014; Bosworth, 2012; 2014). As we observe in those publications, detainees are, on the whole, anxious and depressed, confused and alarmed. These are deeply problematic institutions, with few clear objectives and much, however unintentional, torment many of those they house.

For as long as the British government, like so many others, remains stubbornly attached to detaining foreign citizens as part of their attempts to manage asylum and immigration, it is important to reiterate their deleterious effects on those who are locked up. Detention centres hurt those within them, their families and

\footnotetext{
${ }^{1}$ Each centre runs a shop in which detainees can purchase everyday products as well as lodge mail orders for Argos. The shop is usually staffed by 'civilian' officers (i.e. not DCOs). IRCs vary in what they say they do with the profit; some invest it back into the centre, others do not.
} 
their friends. In the rest of this chapter, however, we want to focus on the implications of IRCs for custodial staff and for our ability to engage with and understand them.

Staff are affected by the uncertainties of detention and by the built environment in which they work. They are also not immune from the uncertain status and legitimacy of these sites. Many find the politically contested nature of IRCs particularly upsetting, and feel frustrated with their negative depiction in the media. Nobody wants to believe they are actively engaged in harming others. Some articulated considerable ambivalence about their job, worrying about its morality and ethical foundations.

Such matters raised distinct challenges for engaging staff in the research project. Like detainees, officers could be mistrustful. Many felt alienated from their colleagues, particularly the senior management team. Under these circumstances, staff participation and perspective was often hard to predict.

Some of the challenges we faced sprang from participants' unfamiliarity with academic research. While a handful of officers and detainees had university degrees, for the rest we were usually the first academics anyone had ever met. They were unsure why we were interested in their stories, nor, what we would do with the information they told us. Often, this circumstance worked in our favour as neither group knew what to make of us, nor had much of a sense of the nature or purpose of academic research. At the same time, however, such ignorance about applied research and publishing made it difficult to obtain informed consent and also to explain our role and responsibilities as scholars. It also made some people suspicious.

Some believed our research would make things better. Senior officers, who had worked in prisons were particularly enthusiastic about our plans to design and administer a survey on the 'quality of life'. Those who were familiar with the MQPL, believed, as a senior member of staff at IRC Colnbrook put it, that the MQLD, had 'huge value for detainees.' (SMT, Colnbrook), and would help them improve their 'service delivery'.

Others were rather more modest in their view of us, believing that our interactions with detainees might simply alleviate some of the anxieties of those in their care. By spending time with detainees some believed we made officers' jobs a little easier. For this alone, some DCOs offered grudging approval. "At the beginning," one DCO confessed in IRC Tinsley House, "we were very suspicious of you but then we saw you were really interested in talking to the men so I hope something good comes out of it..." (Barry, DCO, TH) ${ }^{2}$

As in previous projects, the aspirations of research participants were hard to live up to (Bosworth et al., 2005). Our goal was to understand. Yet, those we interviewed and observed hoped for more. They wanted our research to make things better.

\footnotetext{
2 This is not his real name. All participants cited in this article have been given psuedonyms.
} 
Some officers were clearly uneasy around us. Like the detainees, they sought to know why we had been allowed in to study these secretive sites, when so many others had failed. Unwittingly echoing the words of detainees, ${ }^{3}$ Tim confronted Blerina in the library of Tinsley House, demanding suspiciously 'who are you? You are some kind of a spy. You work for UKBA.' (DCO, TH) In Brook House, Slade was just as blunt, telling Mary in no uncertain terms that 'If it were up to me, I wouldn't let you in here'. (SMT, BH)

Rather than simply ill tempered suspicion, these testimonies capture the uneasy relationship between the Home Office and custodial staff and the lack of clarity many officers felt about the nature of their job. While their concerns were articulated against us, they revealed considerable mistrust and uncertainty within the structures of everyday life and governance in these institutions, at odds with the dominant official representation of such places. Like the civil servant who agreed to the project, staff and detainees were prepared to participate, but they were not entirely sure they trusted us, or anyone else in detention.

Permission to conduct research in IRCs can only be granted by the Home Office. Requests to individual centre managers must be passed onto them. Unlike the National Offender Management Service (NOMS), there is, as yet, no structure for reviewing applications. Instead research requests are managed in an ad hoc fashion, by the head of detention services. This highly individualized and discretionary approach to research access mirrors the immigration system more broadly, where decisions to detain and deport are made on a case-by-case basis. It is currently under review.

In making their decision to allow research, the Home Office do not have to consult the private contractors. However, in the early stages of her project, Mary was invited to pitch ideas to a meeting of the Centre Managers. She has subsequently returned and reported on some of her findings to this collection of senior staff. They remain among the most vocal supporters of research in detention, happier to open the doors of their establishment than their public service 'customer'.

Neither centre mangers nor the Home Office consult detention custody officers or detainees in determining research access. These people, who will have the most contact with researchers, are rarely forewarned. While some centres circulated information about the original project and subsequent activities in advance, DCOs were and often remain unaware of our plans. In each site, reflecting the high turnover of employees, there will always be staff new in post. Others will not have read the email. Still others may have missed a briefing due to their shift pattern. Whatever the reason, in practical terms, we can never rely

\footnotetext{
3 'Why are you here? Jamil challenged Mary. 'Who let you in? Maybe you're from UKBA and everything I tell you, you will go and tell them. I know how the system works. Why should I talk to you?' (Uganda, BH, in Bosworth, 2014: 59).
} 
solely on our formal permission, but rather have had to negotiate and renegotiate our research access in each site.

Staff control and may block our access to and within the centres in a number of ways. Sometimes they refuse entry to the establishment altogether, claiming a lack of proper instructions. More commonly, those on the gate merely delay our entry insisting on confirmation from management before letting us proceed. On one occasion, in Brook House, after a 90-minute drive from Oxford, Mary was not permitted to enter and had to go next door to Tinsley House instead. An irritable fieldnote describes what happened:

I am meant to be at Brook House but not a single member of SMT or UKBA there. So nobody knew who I was and wouldn't let me in. Came to Tinsley House where also suddenly more difficult about access. Just because nobody had been told anything about it. I queried the [visitor's] badge I was given which then lead to a DCO worrying and so am now waiting. I have spent past hour waiting here and Brook House. (Fieldnote March 2011).

They also have subjected us to varying levels of security inspection, sometimes waving us through, at other times searching our clothes, mouths and possessions for contraband. Digital recorders, which are authorized, are often queried. Some places have made us wear badges to identify us as visitors, others have let us wander around without them.

Once within the walls of the centres research access still has to be managed. Fairly early on in the project, we took the decision to carry keys, to reduce our burden on the establishment and to facilitate our freedom of movement. However, this is not always possible, leaving us dependent on DCOs to lock and unlock doors. Even with keys, DCOs and onsite Home Office staff occasionally challenge us directly, querying our presence, intention and viewpoint in front of detainees or colleagues, demanding our opinion of detention, or an account of ourselves. A few have refused to participate altogether, abandoning prearranged interviews, into which their senior management had 'volunteered them' once we informed them that under the University ethics requirements they were free to refuse to participate. Others just kept putting us off, agreeing to be interviewed, but then constantly rescheduling.

Often their reluctance springs from quite mundane sources. DCOs are busy. Time spent with us takes them away from their responsibilities. Yet their reticence is rarely purely pragmatic. Many feel considerable anxiety about their job, its purpose and its security.

While those in senior management sometimes express corporate pride, many uniformed officers feel precarious, complaining frequently about working conditions, pay and scheduling. Few have deliberately sought out a career in detention custody. Most have fallen into it simply as a means of paying their bills. Many work at more than one job, badly paid and vulnerable in each. Some, like Todd, a detention custody officer (DCO) in Yarl's Wood, struggle to cope, 
"I have worked here many years. It is really hard work. I had a nervous break down 5 years ago ... They don't appreciate how hard the work is here. It was much worse when men were here because they were aggressive. But the women are much better. You can make friends with a lot of them. There are rarely any fights. I am most of the time here in visits, I go where they take me. It is hard work and you can't leave it behind. These working hours don't go with family life. Any relationship would break really quickly."

Perhaps for this reason, custodial companies were initially far more concerned about the participation of their staff than they were about us surveying, observing and interviewing detainees. Unlike the questions we posed to detainees, the schedule for formal staff interviews had to be authorized before we could invite officers to participate. While informal interactions with staff were not, to our knowledge, scrutinized, we cannot be sure that staff were not counseled to monitor their behavior with us.

Such matters took us by surprise. While we had braced ourselves for staff suspicion about our interactions with detainees, we had not been prepared for concerns about including officers. We had also not given sufficient thought before we entered the field about how such institutional mistrust would make us feel.

Given our commitment to the research project and the considerable emotional burden it placed on us, small examples of inefficiency or suspicion could often feel more upsetting than perhaps they were intended. In Yarl's Wood for instance, Mary's fieldnotes reveal her irritation with staff coupled with her anxiety about whether she was actually doing the research properly.

I left the dining hall to find loo and go somewhere to write up notes, I was accosted by a staff member: the gatehouse hadn't made me a visitor's badge and he was clearly worried about who I was. As at Campsfield House nobody seems to have been told about me or about my work. Instead I'm just dropped into this. (Fieldnote, June 2010).

While it is tempting to dismiss such events as personal, these examples capture the wider uncertainty and lack of trust that characterizes IRCs. Documented by scholars, activists and government agencies, such uncertainty is not only a distinctive characteristic of detention, but is profoundly corrosive (Bosworth, 2014; Griffiths, 2014; HMIP and ICIBI, 2012). Staff and detainees struggle in this environment of low trust, unsure what to make of themselves and others. It should not be surprising that this backdrop shaped people's willingness to participate in our research.

In a lengthy excerpt from one interview with a DCO in Tinsley House, we see how this officer's uncertainty about us intersected with and amplified his conflicted view of detainees and how to treat them. "At the beginning," Barry told Blerina, "everyone was wondering how you got access from the back door." Why were we there, they wondered and to whom were we actually reporting? Over time, 
however, such concerns ebbed; "I think you have been the most positive influence here. I don't want to say bad things about other people there but you seem to have fitted in here very well." (DCO, TH)

The difference, he noted, was that we were able to spend time with the detainees to garner their trust. "We try not to get to close to them." Barry observed a little regretfully. "You must get much more because you seem willing to hear them talk about anything. We get only parts of the stories and it is understandable they are less willing and trust us less than they trust you." Though seemingly wanting a closer relationship, at least with some of those in his care, Barry made it clear that, trust and openness were simply not possible in his line of work.

Maintaining a level of mistrust and distance, he said, "is one way for us to deal with this job. If we get to close to them it would be very difficult. Like with (name of detainee). Because of how interesting, gentle and nice he was it was very difficult not to like him. So I feel sad for what he had to go through." (DCO, TH).

Constantly enjoined to maintain emotional distance from detainees, officers like Barry were often unsure who or what to believe (Bosworth, 2014; Hall, 2010). This 'culture of mistrust' was exacerbated and underpinned, by the steep hierarchy of custodial posts, in which uniformed 'Detention custody officers' (DCOs) are positioned at the bottom and non-uniformed 'Senior Management team' (SMT) at the top. It also occurred in the context of a tense working relationships in many centres between custodial and Home Office staff, and within an environment in which a limited number of outsiders from charities and voluntary organisations, the medical professions and visiting MPs make occasional appearances (Bosworth and Slade, 2014). No wonder then that some officers were not keen to speak to us.

According to Patenaude (2004), prison staff, administrator and prisoners mistrust researchers because they can not control what each group can say of the others, and potential or criticism. In detention, trust has an additional dimension since those who are detained, are individuals whose story has not been believed. Mistrust under these circumstances is both generalised and particular. Individual detainees attempt to persuade the Home Office their claims are true, while knowing they are part of a group that is constituted by an official view that their claim is groundless.

Staff often claimed skills in differentiating fact from fiction. While they accepted that some detainees told the truth, they were keen to tell us that we would not be able to determine which ones were to be trusted. "It takes a while," Tim said breezily, "but then you learn to see through the lies. It will take some time before they learn to trust you. We have seven guys who have been here for many months and you will get to talk to them quite frankly. Some of the stories are horrific. You will learn to tell the true ones, some are just buried in the truth and some aspects made up" (DCO, TH).

Others simply discounted everything the detainees told them, as the conversation below reveals. After some weeks in detention, Abdi had succeeded in persuading the Home Office he had been tortured and was, as a result 
immediately released. Notwithstanding the efforts undertaken to make the legal case, and significant physical evidence of this man's suffering, one of the officers, charged with this man's care, Tom stubbornly refused to believe his story, steadfastly denying the evidence put forward. Suzan, a female DCO was much more sympathetic towards Abdi's case.

Suzan: "Did you hear that (detainee name) was released? There are people like him who should have never been kept in here, and others that probably should be here. Did you see the signs of physical torture he had in his body?"

Tom: "How do you know he did not do that to himself? Or he could have got one of his friends to do it for him. Don't they do that kind of stuff in their pilgrimage things"?

Suzan: "No. There is no way he could have done that to himself. He had scars on all his body and broken arms and everything. I have never seen anyone with worst scars on their body than him. It was really bad".

Tom: "Well, you must ask yourself what he has done to deserve that and why they did that to him? He must have done something really bad."

Suzan: "Actually in Iran, if nowhere else it is the place where you don't need to do anything wrong to get that done to you. You have no idea what they do to people there."

While Tom's refusal to believe Abdi's claim seems distinct from Barry's regretful distance from detainees, in practice such matters are often connected. Urged by their senior officers to 'empathize', but not 'sympathize,' many officers reported, like Barry, that they avoided learning too much about people's immigration cases and dwelling on the wider, global inequalities these people often represent. "I understand why they do it [come to the UK]" Sam admitted (DCO, TH). "But there is to be a limit. There are not many resources in this country and some of them are a big burden to the system. Like one of the guys who has got problem with this blood, he can't stop bleeding. The doctor had to get an injection for him and he told us that the injection costs more than a family car. I don't know how much that is but it sound like a lot of money. This person might die if he goes back but there needs to be a limit. This country is overloaded anyway... A lot of them come from poor areas where the whole village needs to pay for them to come here and then they pay the village back. I don't blame them for doing it. There are areas people are so poor you see them selling 3 tomatoes on the side of the road to get some money."

As the first systematic study of everyday life in detention it was important to include staff perspectives as well as detainee accounts. Yet, these kinds of statements, in which humanity is denied and social injustice glossed over, are hard to witness without intervening. At such times it was important to remind ourselves that staff were also research participants. We were not there to adjudicate, but rather to document in order to understand. Considered in this light, their perspectives may be viewed as accounts of estrangement (Ahmed, 
2000), words that render powerfully and persuasively the difficulties inherent in and violence of forcing people out of the country (Bosworth, 2014). Less conceptually, they show the personal nature of working in coercive environments designed to expel, raising urgent questions about the ethics and costs of this form of confinement.

\section{Getting out}

While gaining access to conduct research and persuading people to participate can be difficult, so too is leaving. Whereas quantitative colleagues aim for a particular sample size, such matters in qualitative research are notoriously fuzzy. Numbers will not provide the clue, but we depend on rather less welldefined concepts like 'saturation' or 'understanding.' The challenges, in articulating such matters, are manifold, and encompass practical and emotional concerns. When it is time to leave? How will we know? More intimately still, how does a researcher say goodbye? Do we stay in touch?

As this was the first project of its kind, we were keen to include as many sites as possible. Indeed, whereas Mary had first envisaged just two or three institutions, by the end of the first two years, she had spent considerable time in 6 detention centres. Six years on, the numbers of IRCs in our research continue to grow (Bosworth and Turnbull, 2015).

Sometimes, external factors determine the end point of research. The first site in this project was IRC Campsfield House, just outside Oxford. Mary began working there in November 2009. She moved on in January 2010, when another centre, IRC Colnbrook asked to be included after hearing Mary present her ideas at a meeting of the Centre Managers. A former prison governor, this centre manager hoped research could improve how her establishment ran. Familiar with prisons research, she hoped that a similar body of work on the detention estate might be harnessed to ameliorate conditions and improve governance.

Anxious to gain as much experience across the detention estate, Mary felt it was important to take up any and all offers within the two years of funding she had available, even though she remained doubtful about the possibility of meaningful reform in the sector. She also sought to include examples from all the custodial providers, to determine whether there were any substantial differences among them.

Fieldwork in the final site of Morton Hall had to be fitted into a new colleague's summer research plans, before he took up a new post abroad (Bosworth and Slade, 2014; Bosworth, Kellezi and Slade, 2012). Blerina had stopped, not just because of funding, but also because of pregnancy. Such factors have little methodological justification, and may even complicate best-laid plans. Yet, they often characterize the hidden aspects of the research process which usually proceeds alongside other aspects of academic and personal life, such as teaching, family responsibilities, health and holidays. 
Even as the research continues, there are internal endpoints. While ethnography invites ongoing interactions, a survey can only be completed once. Hemmed in by funding and short time scales, even unstructured interactions can be focused. Despite appearances, the researcher is often quite deliberate in her encounters. This is not always easy to do as Blerina acknowledged in her fieldnotes, "What I am finding hard now is the sense that once I know their story I don't make much of an attempt to approach them. I have their stories already." (YW, August 2010).

The emotional demands of fieldwork can, sometimes, be overwhelming and may also become grounds for moving on. Both of us occasionally left early, unable to absorb any more pain, suspicion, confusion or hostility. Crying detainees, intolerant staff, and an unwelcome environment took their toll. During the research period and some months thereafter, we both suffered emotional and physical effects from sleeplessness to anxiety and palpitations. It was difficult to find a way of discussing the research, let along analyzing the findings, without feeling emotionally overwhelmed.

At the same time, however, we both expressed ambivalence about departing. We were worried about losing contact with people with whom we had forged a connection and worried that we had not done enough to help them. Above all, we felt guilty. Blerina worried about such matters almost from the beginning, noting, just six weeks into the project that, "It is strange but I am feeling anxious and sad about the time when I will stop coming to YW. I will have no way of knowing what is going to happen to all these people and I find some of them really special," (BK, YW, August 2010). As her time at Yarl's Wood started to draw to a close, she noted her guilt. "I feel like I am abandoning them. I don't feel that I have been helping them anyway, as I watch powerless while people are being deported. But I feel like I am abandoning them." (BK, YW, November 2010)

Such concerns spring from the emotional weight of this particular research project and the unhappiness we witnessed. They raise broader questions, however, about the purpose of academic study that scholars rarely publically acknowledge. Leaving is hard when you are unsure what you have achieved and when it is not clear what you should be trying to do. What can and should academics do if we fundamentally do not believe that the institution we are studying is justified? Is it possible to influence progressive reforms? In a longterm project, other issues arise. Given the initial warning 'to embarrass' the Home Office, as the first stage of fieldwork came to an end, Mary wondered what that meant. Would she be allowed back in, once she published?

\section{Getting back}

While some researchers may finish a project only to turn to another quite different topic, it is more common to maintain some level of consistency across an academic career. In thinking about research access, therefore, it is important to reflect on the feasibility of return. How can return be secured and what might put it at risk? Can criticism be communicated without alienating gatekeepers? 
Such questions direct our attention to the, often thorny, relationship between the government and the academy, and, particularly to questions about criminology and the state. As British universities become urged to provide evidence of 'impact' beyond the academy, studies this like, with its scope for influencing policy, practice and public debate, are increasingly promoted by administrators. Yet, as criminologists know all too well, impact on policy matters can be elusive. It may also have unintended consequences. The Border Observatory, at Monash University, for instance, who created the first list of border deaths in Australia, were horrified to find their statistics cited by the government of Tony Abbott as justification for the success of their scheme to 'turn back the boats.' As the number of deaths at sea fell on the Observatory's list, the Prime Minister's office pointed to it as evidence of his humanitarianism.

There are many examples of narrowing research, particularly in the field of custody (Wacquant, 2008; Simon, 2000; Hannah-Moffat, 2011). Prisons in the USA are notoriously difficult to access, as they have become in Canada. Whereas the UK has a long and robust tradition of prison sociology, IRCs remain, for most, inaccessible. Instead, and notwithstanding a burgeoning field of study on immigration control, asylum and refugees (Bhatia, 2014), researchers find it difficult to enter these sites.

There is no straightforward explanation of or strategy for maintaining access. This project proceeded according to the usual tenets - an intensive period of fieldwork followed by a longer time devoted to writing. With no restrictions on publication, we were able to produce a range of outputs aimed at different audiences. Early on, acknowledging the institutional interest in the MQLD survey, we presented the research findings to centre managers and civil servants, as well as produced a statistical report for them (Bosworth and Kellezi, 2012). We did not feed back directly to the DCOs or detainees.

At a rather more sedate pace, we have also published a number of academic outputs (see, for example, Bosworth, 2012; 2013; 2014; Bosworth and Kellezi, 2014). Produced singly and together these accounts cover a wide range of issues and formats. While ostensibly in the public domain, they are likely to be rather difficult for those outside the academy to locate and access, allowing for more conceptual reflections as well as more detailed, empirical accounts. These have also all been critical.

Both kinds of publications have occurred alongside oral dissemination. In 2012 Mary created a website, blog and social media accounts on 'Border Criminologies' which have all widened the reach of her research findings. She has been consulted by the Council of Europe on detention conditions and by the authors of a recent review of conditions at Yarl's Wood on aspects of gender and detention. She contributed the literature review on mental health to the independent investigation into welfare in the immigration detention estate headed by Prof. Stephen Shaw.

During the time it took Mary to publish her research monograph (Bosworth, 2014), the civil servant in charge of removals and enforcement changed three 
times. This personnel turnover has effectively erased any direct chain of responsibility for the decision to permit the original study. Rather than weakening her position in the field, the erasure has probably strengthened it, as incumbents can deny responsibility for her findings. At the same time, sufficient senior members of staff in the Home Office and in the custodial companies remain, offering an important line of continuity so that research relationships do not have to be fully recreated each time.

Over the past six years, there have been a series of ongoing meetings and discussions. A second round of the survey has been conducted and published (Bosworth and Kellezi, 2015), with plans underway for a third application. Copies of the monograph, post-publication, were given to the centre managers and Home Office staff. Some keep them in their office and make them available to their colleagues. The head of operations contributed to an open access edited collection on migration control (Abdel-Hady, 2013).

Given the ongoing barriers to research that others interested in immigration detention face, it is difficult to know precisely why our research continues to be supported. The passage of time has certainly played a role. Over six years, relationships of trust have had ample time to develop. People have also just become used to our presence. At least in the Home Office and with the centre managers we are familiar figures. While the past does not guarantee the future, it may help assuage some fears.

So, too, the mixed methodology has been successful. The MQLD survey is widely approved. Staff understand that a quantitative tool requires lengthy qualitative research, and have been patient in our requests to return and revisit their institutions.

From the very beginning we benefited from the importation of research culture from the prison service among staff throughout the detention estate. Whatever our own doubts about the possibility of reform in this sector, such contacts have been extremely useful. Anecdotally some centre managers have told us our research has inspired them to expand their provision of welfare services in IRCs, and to pay more attention to staff morale.

Acknowledging the discretionary nature of decision making in the immigration system, we have expended a lot of effort in maintaining collegial relationships with centre managers and civil servants. Centre managers have often been our biggest champions, encouraging the Home Office to allow us in, and permitting a range of additional projects on art and craft, photography with staff as well as detainees. Charged with the complicated job of confining those awaiting expulsion, these individuals appreciate the potential of academic scholarship, aware of the role it has played in the prison service, hopeful it could be as useful in their line of work. Some civil servants do as well. They too, on occasion, express reservations about their job, distinguishing between their personal beliefs and the expectations of their job, acknowledging inefficiencies or individual cases. Mindful of the limited opportunity for critique, and the close 
scrutiny of MPs, members of the Home Office on site and further afield also, sometimes, evidently hope our work may help them make matters better.

\section{Conclusion: Academic research and policy impact}

At the best of times, custodial research is emotionally and ethically challenging. Conducting research in highly politicized and hidden sites like IRCs is even more difficult. The varied expectations and aspirations surrounding our research often feel overwhelming. The relationship between understanding and reform is not a simple one.

While we aspire to 'make a difference', we are mindful that academic scholarship is neither purely policy-oriented, nor produced on the same time frame. So far, we have managed to act as 'critical friends' thereby perhaps not straying as far from prison studies as we had thought, notwithstanding our far more limited scale of research (Liebling, 2010). As the rhetoric and law surrounding migration control continues to harden, however, questions remain over how long this kind of relationship will last.

It is not at all clear that IRCs are sites that can be improved. To do so, would be to accept they are justified, which we do not. So many of the challenges staff and detainees face stem from border control more generally and the exclusionary politics they embody and promote. To this challenge, we have no easy answer. While some might argue that our presence legitimates the structure, or worse, due to our disciplinary home, that we exacerbate them, both charges overstate the role and impact of academic research. IRCs and border control will continue irrespective of our presence for as long as they are politically expedient. Our role remains, after all these years, primarily to understand them.

Through documentation, bearing witness and describing them, we gather evidence of their nature and effect. Working alongside the staff and detainees, gathering information, we look for explanation and detail, pointing out their uncertainties, contradictions, pains, and occasional moments of joy, creativity and compassion. The details we gather reveal over and over again, the contested, painful and uncertain nature of these sites. They also demonstrate our shared humanity with those within. Such accounts, in the current political climate, may not seem like much. Yet, this surely is the task of academic research:

documenting, interpreting, and analyzing in order to understand. We may not be able to force change, but we certainly can and must argue for it where possible. 


\section{References}

Aas, K. F., and Bosworth, M. (Eds.). 2013. Borders of Punishment: Migration, Citizenship and Social Exclusion. Oxford: Oxford University Press.

Abdel-Hady, K. 2013. Interview. Prison Service Journal. 205: 8-9.

Ahmed, S. 2000. Strange Encounters: Embodied Others in Post-Coloniality. London: Routledge.

Bhatia, M. 2014. Researching 'Bogus' Asylum Seekers, 'Illegal' Migrants and 'Crimmigrants.' In K. Lumsden and A. Winter (Eds.), Reflexivity in Criminological Research: Experiences with the Powerful and the Powerless: 162177. London: Palgrave.

Bosworth, M. 2014. Inside Immigration Detention. Oxford: Oxford University Press.

Bosworth, M. 2013. Can Immigration Detention be Legitimate? In K.F. Aas and M. Bosworth (Eds.), Borders of Punishment: Migration, Citizenship and Social Exclusion: 149-165. Oxford: Oxford University Press.

Bosworth, M. 2012. Subjectivity and identity in detention: Punishment and society in a Global Age. Theoretical Criminology. 16(2): 123 - 140.

Bosworth, M. 2007. Immigration Detention in Britain. In M. Lee (Ed.), Human Trafficking: 159-177. Collumpton: Willan Publishing.

Bosworth, M. 1999. Engendering Resistance: Agency and Power in Women's Prisons. Aldershot: Ashgate Press.

Bosworth, M., \& Kellezi, B. 2015. Quality of Life in Detention: Results from the MQLD Questionnaire Data Collected in IRC Campsfield House, IRC Yarl's Wood, IRC Colnbrook and IRC Dover, September 2013 - August 2014. Oxford: Centre for Criminology.

Bosworth, M., \& Kellezi, B. 2014. Citizenship and Belonging in a Women's Immigration Detention Centre. In C. Phillips \& C. Webster (Eds.), New Directions in Race, Ethnicity and Crime: 80-96. Abingdon: Routledge.

Bosworth, M., \& Kellezi, B. 2013. Developing a Measure of the Quality of Life in Detention. Prison Service Journal. 205: 10 -15.

Bosworth, M., \& Kellezi, B. 2012. Quality of Life in Detention: Results from the MQLD Questionnaire Data Collected in IRC Yarl's Wood, IRC Tinsley House and IRC Brook House, August 2010 - June 2011. Oxford: Centre for Criminology.

Bosworth M, Kellezi B, Slade G. 2012. Quality of Life in Detention: Results from Questionnaire Data Collected in IRC Morton Hall, Oxford: Centre for Criminology

Bosworth, M., \& Slade, G. 2014. In Search of Recognition: Gender and StaffDetainee Relations in a British Immigration Detention Centre. Punishment \& Society. 16(2): 169 - 186.

Bosworth, M., \& Turnbull. S. 2015. Immigration Detention and the Expansion of Penal Power in the UK. In K. Reiter \& A. Koenig (Eds.), Extreme Punishment: 50. London: Palgrave.

Crewe, B. 2009. The Prisoner Society. Oxford: Oxford University Press.

DeGenova, N. 2010. The Deportation Regime: Sovereignty, Space and the Freedom of Movement. In N. De Genova and N. Peultz (Eds.), The Deportation Regime: Sovereignty, Space and the Freedom of Movement: 33- 68. Durham, NC: Duke University Press.

Griffiths, M. 2014. Living with Uncertainty: Indefinite Immigration Detention. Journal of Legal Anthropology, 1(3): 263 - 8. 
Hall, A. 2010. These People Could be Anyone: Fear, Contempt (and Empathy) in a British Immigration Removal Centre. Journal of Ethnic and Migration Studies, 36(6): 881 - 98.

Hall, A. 2012. Border Watch: Cultures of Immigration Detention and Control. London: Pluto Press.

Hannah-Moffat, K. 2011. Criminological cliques: Narrowing dialogues, institutional protectionism and the next generation. In M. Bosworth \& C. Hoyle (Eds), What is Criminology?: 440-455. Oxford: Oxford University Press.

HMIP. 2002. An Inspection of Campsfield House Immigration Removal Centre. London: HMIP.

HMIP and ICIBI, 2012. The Effectiveness and Impact of Immigration Detention Casework: A Joint Thematic Review. London: HMIP \& ICIBI.

Kaufman, E. 2015. Punish and Expel. Border Control, Nationalism, and the New Purpose of the Prison. Oxford: Oxford University Press.

Klein, A., \& Williams. L. 2012. Immigration Detention in the Community: Research on the Experiences of Migrants Released from Detention Centres in the UK. Population, Space and Place, 18(6): 710 - 14.

Liebling, A. 2010. Being a Criminologist: Investigation as a Lifestyle and Living. In M. Bosworth \& C. Hoyle (Eds.), What is Criminology?: 518 - 529. Oxford: Oxford University Press.

Liebling, A. 2004. Prisons and their moral performance. Oxford: Oxford University Press.

Phelps, J. 2009. Detained Lives: The Real Cost of Indefinite Immigration Detention. London: LDSG.

Patenaude, A. L. 2004. No promises, but I'm willing to listen and tell what I hear: Conducting qualitative research among prison inmates and staff. The Prison Journal, 84(4 suppl), 69S-91S.

Philips, C. 2010. The Multicultural Prison. Oxford: Oxford University Press.

Silverman, S., \& Massa, E. 2012. Why immigration detention is unique. Population, Space and Place, 18(6): 677 - 86.

Simon, J. 2000. The "Society of Captives" in the Era of Hyperincarceration. Theoretical Criminology, 4(3): 285 - 308.

Sparks, R., Bottoms, A. E., \& Hay, W. 1996. Prisons and the Problem of Order. Oxford: Oxford University Press.

Wacquant, L. 2008. The curious eclipse of prison ethnography in the age of mass incarceration. Ethnography, 3(4): 371 - 97. 